\title{
COVID-19's Impacts and the End of Globalization?
}

\author{
Benjamin Mwadi Makengo \\ School of Politics and International Studies, Central China Normal University, Wuhan, China \\ Email: benjaminmwadi@yahoo.com
}

How to cite this paper: Mwadi Makengo, B. (2021). COVID-19's Impacts and the End of Globalization? Open Journal of Social Sciences, 9, 212-233.

https://doi.org/10.4236/jss.2021.91015

Received: December 10, 2020

Accepted: January 16, 2021

Published: January 19, 2021

Copyright $\odot 2021$ by author(s) and Scientific Research Publishing Inc. This work is licensed under the Creative Commons Attribution International License (CC BY 4.0).

http://creativecommons.org/licenses/by/4.0/

\begin{abstract}
With the COVID-19's impacts to humanity, some have quickly shouted, believed and thought abusively to the end of globalization. But in this paper, following to the dimension of the strategic approach of analysis, tinged with a bit of globalism, I propose to explain why globalization could not end with the COVID-19's impacts. In total, I advance successively throughout this paper, five (5) core arguments, which together ostensibly support my central point, pointing to the impossibility of arriving at the end of globalization with the COVID-19's impacts. These five (5) core arguments are: COVID-19 as a proglobalization messenger: "You are living in a global village" (i), Virus Complex nature (ii), Nationalism and Unilateralism as COVID-19's counter-antidote strategies (iii), COVID-19's Impacts Nature on Social-economic activities (iv), and the Global Complex Interdependence (v). And instead of shouting to the end of globalization, humanity should rather seek to think about, understand and internalize the different lessons that COVID-19 has just come to give it-for its best survival. Otherwise, disaster is coming.
\end{abstract}

\section{Keywords}

COVID-19's Impacts, End of Globalization, Humanity's Strategies against COVID-19, Humanity's Better Survival in the Face of COVID-19

\section{Introduction}

Based on the general observation made, about a year already, humanity keeps being in mask mode ${ }^{1}$. Despite an improving trend in some parts of the world, the overall number of people infected with COVID-19 continues to increase on a daily basis ${ }^{2}$. Not easy to digest of course! But alas! It is embarrassment, fear,

${ }^{1}$ The wearing of masks has become a way of life for mankind, a particular way of survival in this COVID-19 era. It was in January that COVID-19's news began to spread around the world.

${ }^{2}$ According to Johns Hopkins University Coronavirus Resource Center, since April 2020, an improving trend has been observed in Northeast Asia-in China, Japan and South Korea... And the overall number of people infected with COVID-19 reached 66,561,559 on December 6, 2020 compared to 67592458 on December 8, 2020. 
stress-although, until proven otherwise, being infected or succumbing after being infected is not in itself a fatality. The large and growing number of healed people around the world can testify to this ${ }^{3}$. Indeed, COVID-19 appears to be not only highly contagious, but also fatal. It kills! That is how the world mourns. So, despite the fact that the mortality rate due to COVID-19 is trending downwards in different parts of the world, the overall number of deaths due to this pandemic continues to increase day by day-the deaths that this paper pays tribute to ${ }^{4}$. Until an effective vaccine's distribution ${ }^{5}$, lockdown, physical or social distancing, hygienic conditions, masks and mass testing remain the main bulwarks of states in the face of this COVID-19 pandemic. The heroes on the front line, particularly the medical profession as a whole, continue to give the best of themselvesthe heroes whom this paper sincerely thanks. Ostensibly, thanks to their determination and Hercules' work, the light at the end of the tunnel is still shining, the light of hope for the return of life before COVID-19-although uncertainties still reign for that. Until proven otherwise, no one knows what time or day this pandemic will end. Some already believe that humanity should learn to live with COVID-19-as it does with other infectious and seasonal diseases ${ }^{6}$.

All this just shows the complexity of the [almost unknown] virus causing this pandemic. Until further notice, no one and no one can pat themselves on the chest and say they have absolute control over COVID-19-especially its origin, speculation upon speculation until proven otherwise (Makengo, 2020c: pp. 188203). Yes, COVID-19 is still surrounded by several mysteries. The origin of the virus, the totality of its modes of transmission, its fixed, neat and exact treatment, and the disparities in its spread in different corners of the world-particularly the low rate of its spread on the African continent compared to other continents with the most advanced sanitary facilities-all remain, until proven otherwise, mysteries (Makengo, 2020b, pp. 113-129). And it is the complexity of this new coronavirus, due to its many mysteries, that has inevitably led to the "strategic retreat" of humanity in its fight against it. The enemy is invisible and complex, and has rapidly gained ground. Humanity, surprised by COVID-19, its cries of combat ${ }^{7}$-expression of its concern at the COVID-19's impacts, did not take long to rise, I quote: Caution! Help! Let's go back home! Stay in your country! Stay home! I suspect you! I accuse you! Let's collaborate! Solidarity! Myself

\footnotetext{
${ }^{3}$ According to Johns Hopkins University Coronavirus Resource Center, the overall number of people cured from COVID-19 reached 42,814,749 on December 6, 2020 out of 66,561,559 of the total number of infected people.

${ }^{4}$ According to Johns Hopkins University Coronavirus Resource Center, the overall number of deaths due to COVID-19 reached 1,529,969 on December 6, 2020 compared to 1,544,543 on December 8, 2020.

${ }^{5}$ Towards the end of November and the beginning of December 2020, news of effective vaccines continues to come from everywhere. Vaccines from Moderna, Pfizer, AstraZeneca, Sinovac, Oxford and the Russian sputnik v vaccine are already announced to be effective. Just mankind is waiting to see their effectiveness on the ground.

${ }^{6}$ In mid-May 2020, various medical experts, as well as those from the WHO, suggested that COVID19 may "never go away" and then become a disease that humanity will have to learn to live with.

${ }^{7}$ The cries expected, followed and observed in different parts of the world.
} 
first, others after! Let's protect and bring our companies and investments back home! Cries that others do not seem appropriate in a fight against a common enemy-if COVID-19 should be considered as a common enemy of humanity. Residing myself in Wuhan, the city where COVID-19 was discovered at the first-this retreat and cries of humanity came practically from everywhere-I experienced them well, heard and witnessed them in a fresh way and not via the second hand.

As a result, national, international and global flows have ostensibly reduced to a very low level-especially depending on the physical dimension, contrary to the digital one. The conditional quickly predominated when talking about the mobility of people, goods and capital not only nationally but also internationally and globally. No more mobility as before! Roads, bus stops, train stations, airports and ports... have been transformed into quasi-deserts, dominated by an almost "apocalyptic silence". Socio-economic and financial crises-free falls in the growth of gross domestic product (GDP) both worldwide and in individual countries around the world-recessions-were quickly observed (Makengo, 2020b). "Ad hoc nationalisms" emerged. Multilateralism no longer seemed to be important-especially with the finger-pointing, by the Trump Administration, at the World Health Organization (WHO), also very abusively at China (Makengo, 2020c). This quickly brings up the abusive reasoning from the rest of the worldparticularly from the Western world and their allies-going in the same direction as the Trump Administration's statements (Makengo, 2020c). And the questions that arise here are: is this not the beginning of the "de-globalization" or the end of globalization? Are we really moving towards the end of globalization with these COVID-19's impacts? Did COVID-19 really come to put an end to globalization? Can we really talk about the end of globalization with the COVID-19's impacts? Should the COVID-19's impacts make us think or believe to the end of globalization? Could COVID-19's impacts really put an end to globalization? And why? All these questions still divide the opinions, comments and arguments of different researchers and commentators around the world.

Some have abusively shouted and thought to the end of globalization with this COVID-19 pandemic $^{10}$. Moreover, they have focused on the socio-economic-political dimension of globalization, based on the ostensible reduction of global flows and mobility, the law of supply and demand and the rise of "ad hoc nationalisms". They quickly forgot that globalization is indeed a multidimensional and complex phenomenon, and cannot be understood just by looking at one or some of its dimensions (Steger, 2003: pp. 37-93). The "world's factory"-China, touched at the heart by COVID-19, the rest of the world thought it was caught in its grip-

${ }^{8}$ I experienced it with my own eyes in Wuhan city, and through the news of different international media, in different corners of the world, especially in France in the city of Paris, in Italy in its major cities, in Spain...

${ }^{9}$ Circumstantial nationalism.

${ }^{10}$ In particular, some of the Western scholars, whom I would not have named here, perhaps some of them have already changed their minds. 
and would not get out of it. The world's supply is under attack, and has begun to breathe in masks. Breathing in mask mode! It's panic on the global and national market. The spread of the virus to the rest of the world's corners has further raised the perception of the proponents believing in the end of globalization with the COVID-19 pandemic. Because the global demand and the rest of the world's supply are now also affected. This is the crisis in supply and demand. Woe and disaster to the future of the world economy! The "ad hoc nationalisms" - that is to say, circumstantial nationalism-have been on the rise. Cries of ${ }^{11}$, I quote: let's only consume our own products! Let us protect our own investors and entrepreneurs! Let's make our investments, companies, businesses and factories return home! Let us put ourselves first, others afterwards! And so, it is this crisis of supply and demand, coupled with the rise of "ad hoc nationalism" that has ostensibly prompted many to shout, believe, think and swear that globalization is coming to its end. From this perspective, some of them believed that COVID-19 had just come to play the role of gas pedal to the "de-globalization" vision that was already under the table of the various global actors ${ }^{12}$. The quasi-immobility of people, goods and capital at the national, international and global levels made possible by COVID-19, just prevailed in their analysis. Beyond other dimensions of globalization that were omitted from their thinking, they almost forgot that only the mobility, the spread of the virus causing COVID-19-via its different modes of transmission: inter-human or not-in the different world's corners, is indeed part of globalization ${ }^{13}$. Human interconnection may well be separate, but that of nature is unbreakable. And even if the desires of certain-particularly of the Trump Administration-were to increasingly call for a "de-globalization" vision with a view to "re-globalization ${ }^{14}$," its realization should not be thought of with COVID-19. To think this way, reveals a great deal of absurdity. Because COVID-19 did not come to play the springboard for the end of globalization. Even if it did, globalization, which has become increasingly complex since the beginning of the twenty-first century ${ }^{15}$, could not end overnight. In spite of the paradoxical globalization (Rodrik, 2011: pp. 1-301) and the rise of the anti-globalization movement (Buckman, 2004: pp. 1-229), it is indeed a great illusion to think or believe to the end of globalization with the COVID-19 pandemic.

Thus, following to the dimension of the strategic approach of analysis (Crozier and Friedberg, 1977: pp.1-436), tinged with a bit of globalism (Jamil, 2011: pp. 1-212), and with a fresh eye, this paper proposes to explain why the COVID-19's impacts could not lead to the end of globalization-the end of in-

\footnotetext{
${ }^{11}$ These cries had been heard more in the Western world, to mention only in France and United States.

${ }^{12}$ Especially with the Trump Administration's push to trade wars and isolationism.

${ }^{13}$ The virus causing COVID-19 is quite complex, its mobility in its various modes of transmission quasi-unknown-all of them-is well and truly part of globalization. It is "virological globalization" -the complex mobility of the virus at the global level, which is linked to the "nature globalization" -the global interconnectedness of nature.

${ }^{14}$ To destroy and globalize again.

${ }^{15}$ Especially with the rise of China through its mega-project of Belt and Road Initiative.
} 
terdependence, mobility and inclusion at the global level. I put forward five (5) core arguments that are supported my main hypothesis-pointing to the impossibility of arriving at the end of globalization with the COVID-19's impactswhich are going to be outlined in the following lines. These five (5) core arguments are: COVID-19 As A pro-globalization messenger: "You are living in a global village" (i), Virus Complex nature (ii), Nationalism and Unilateralism as COVID-19's counter-antidote strategies (iii), COVID-19's Impacts Nature on Social-economic activities (iv), and the Global Complex Interdependence (v). Taken together, they better explain why globalization could not end with the COVID-19's impacts.

\section{COVID-19 as a Pro-Globalization Messenger: "You Are Living in a Global Village"}

COVID-19's greatest message to humanity is not that of de-globalization or to put an end to globalization, I quote: de-globalize! Finish with it! Give it up! No and no! But rather, this message is very revealing of the current state of humanity, I quote: "you are living in a global village". This is the COVID-19's ultimate message to humanity-revealing to us in a pronounced way that we are indeed living in a global village. A reality that humanity increasingly seemed to forget, ignore, neglect or divide for its own sake. Some-such as the Trump Administration-just for strategic reasons and national interest, no longer believe in this reality of a globalized world (Makengo, 2020d: pp. 117-143). Instead, they brandish their nationalist visions-to quote only: "America first?" - in the sense of putting their own national interest first-at the risk of being "dribbled" by others, particularly by rising China (Makengo, 2020d: pp. 124-128). What if it was just paranoid? While some of them-to mention only the United States-from the end of the Second World War to the end of the Cold War and the very beginning of the twenty-first century, have been the promoters of the world's push towards this reality of the global village (Makengo, 2020d). This one, being transformed into a global village, they no longer want it! Others, on the other hand-like China-for strategic reasons, also to a certain extent, ostensibly believe in this reality of a globalized world (Makengo, 2020d: pp. 128-132). And they also tirelessly promote the globalizing vision of humanity, to quote here only the thought that keeps coming up in the speech of Chinese President Xi Jinping-as was also the case with his predecessor Hu Jintao-I quote: " $A$ community with shared future for mankind” (Xi, 2017: pp. 569-588; Xi, 2014: pp. 1-512).

Alas! Everything has become clear now. This debate of the century is well settled for the moment. The conclusion is quite clear. The thought of a globalized world has been well asserted in a very pronounced way with the arrival of COVID-19. The latter has clearly shown that the world is small. Its greatest message to humanity already pinned above is very eloquent on this point, I quote: "you are living in a global village". Yes, all of humanity should accept and take note of this reality, I quote: we are living in a global village. But just, it is the mi- 
srepresentation of the COVID-19's ultimate message to humanity that has led some to believe and cry out to the end of globalization. They were mistaken not only by the rise of the "ad hoc nationalisms" of the COVID-19 era, but also by the cries that came out here and there, I quote: "Let's go back home! Stay in your country! Stay home! I suspect you! I accuse you! Me first and the others after! Let's protect and bring our businesses and investments home! They haven't gone to the depths to find out why the virus is spreading so rapidly throughout the world. And they also misinterpreted the COVID-19's ultimate message to humanity-as just shown in the Figure 1 below.

This ultimate message from COVID-19 to humanity, as shown in the figure above, does not call to the end of globalization. Rather, it calls for awakening, effective organization, collaboration, cooperation, solidarity, harmony and responsibility. Let us wake up! Let's organize effectively! Let's collaborate! Let's cooperate! Long live solidarity and harmony among us! Let us be consistent and responsible in our actions and decisions! Humanity is almost bound to a common destiny. No one and nobody can survive and protect themselves absolutely well on their own. Protection, in all its aspects, should go beyond the national dimension to embrace the global one. A deviant decision or action-taken or done in an individual way-may well manage to affect the different world's corners. This is no longer only the logic of the famous thought, I quote: "Think global, act local' (Shannon, 2002: pp. 26-29). But also well, we should now: think global, act local and global at the same time. These are the contents of COVID-19's ultimate message to humanity, which are well opposed-as demonstrated and explained in the lines above-to any de-globalizing vision or one pushing toward the end of globalization. Rather, it is a challenge to humanity. The message, reality and interpellation that all humanity should understand and

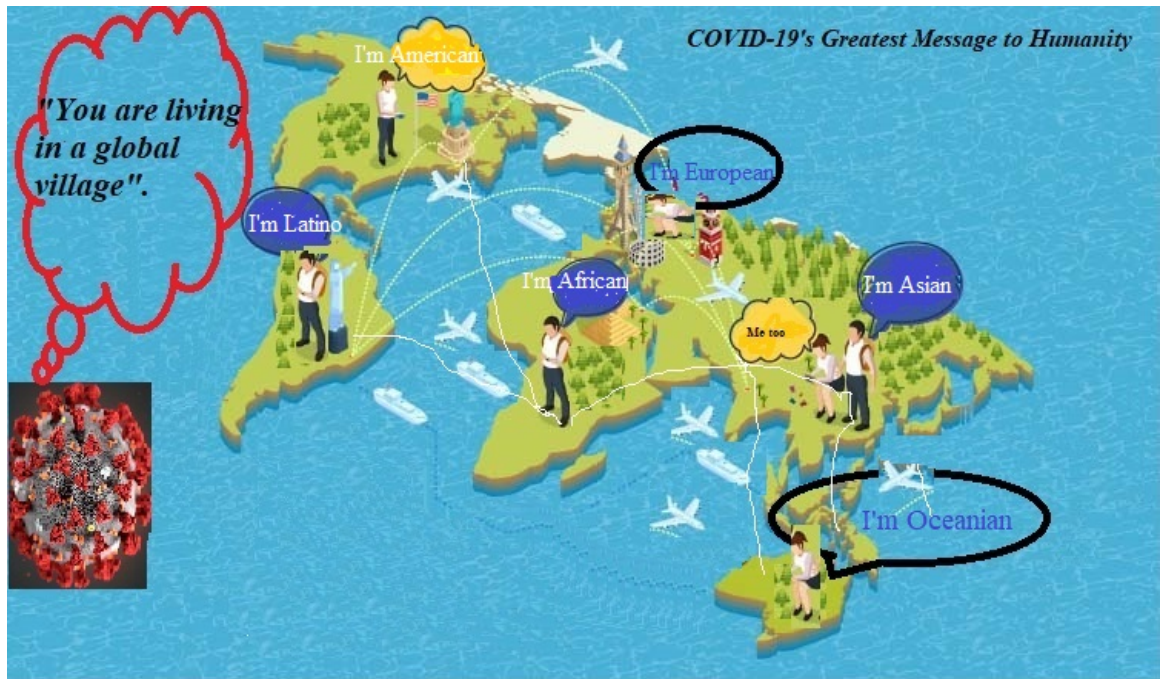

Source: The image modified by myself on the basis of the image coming from https://www.9changes.com/what-english-does-to-make-the-world-a-global-villagel, accessed the $29^{\text {th }}$ November 2020.

Figure 1. COVID-19's greatest message to humanity: "you are living in a global village". 
internalize for its better survival. COVID-19, has just come to show us that we are living in a global village, not pushing humanity to the end of globalization.

\section{Virus Complex Nature}

I am not a physicist, virologist or medical staff to speak here about the details of the nature of the virus causing the COVID-19 pandemic. Rather, I am merely an observer of society. But just, you only haven't to be a medical specialist to realize that the nature of the virus causing COVID-19 is complex. Its origin alone, so far, is not yet clear. The conspiratorial theories-abusively fingering mainly the Chinese virology lab P4 in Wuhan-wanting to explain the origin of this new coronavirus, have now gone under the bushel and become downright amphibological (Makengo, 2020c). The bat, the pangolin, the snake... are constantly being whitewashed by virological scientists seeking to explain the origin of this new coronavirus $^{16}$. Whereas since the official discovery of this virus by Chinese virologists, almost all of humanity has not stopped pointing the finger at these poor animals ${ }^{17}$. And the famous Huanan market in Wuhan-where it was wrongly assumed to be the starting point for the spread of the virus-is thus narrowly saved $^{18}$.

Beyond its origin, it is its modes of propagation that make it even more complex. This new coronavirus is practically quasi-unknown about the different modes of its propagation ${ }^{19}$. The virus has even managed to penetrate and affect some of the safest and most protected places and people in the world. I am thinking here to the White House, the Royal Palace of the United Kingdom, the American President Donald Trump, the Prime Minister of England Boris Johnson... The virus is ostensibly surrounded by many of the mysteries for its modes of transmission. Some are contaminated while inside submarines on mission before the discovery of the virus. I am thinking here of the mysterious contaminations in April of about fifty French sailors inside the Charles de Gaulle ship on mission. Others were contaminated while traveling by air and sea. What is even more mysterious is the pronounced disparity in the spread of the virus in different parts of the world. The low level of the virus' spread on the African continent has beaten all the prognosis-who have always believed the worst in Africa, which is under-equipped in everything. Isn't it a great mystery? Until proven otherwise, there is no concrete and exact explanation for this (Makengo, 2020b).

And furthermore, the changes in strategies and methods to avoid being infected with the virus, and to contain it, may well also be sufficient proof of the

\footnotetext{
${ }^{16}$ Virologists around the world, themselves, have managed to sweep away the early ideas behind COVID-19's origin, pointing to a number of the animals. Until proven otherwise, COVID-19's origin is not yet known.

${ }^{17}$ This is how eyes were abusively turned to the famous Chinese market in Huanan, where these animals can be found for purchase.

${ }^{18}$ According to the latest research by Chinese virology experts, the Huanan market is no longer the epicenter of COVID-19. Until proven otherwise, the exact location of the beginning of COVID-19 is not yet known.

${ }^{19}$ Changing strategies for coping with it may well demonstrate this.
} 
complexity of this new coronavirus. For the same virus, the wearing of masks, lockdown, physical distancing... were not considered so necessary at the beginning of the pandemic, after the publication of other research, they all became obligatory-until they were transformed to the last ramparts of humanity in order to face COVID-1920. Also, the treatment of people infected with the virus is still complicated, and has been further revealed the complexity of this new coronavirus. Saliva continues to flow for the therapy of COVID-19. Just to mention here the famous debates about the use of hydroxy-chloroquine and other drugs ${ }^{21}$. Myself, while being in the city of Wuhan-where the virus was discovered at first - I have lived, observed and followed with a magnifying glass the history that surrounds the complex nature of this new coronavirus in all its aspects that I wouldn't have told here ${ }^{22}$. Just as the Figure 2 below tries to demonstrate the complex nature of this new coronavirus, following the thread of thought noted here in this point.

And this complex nature of the virus pinned above, does not call to the end of globalization, as some have abusively thought. Rather, it demonstrates, on the one hand, that this virus is itself a factor of globalization. This is what I call "virological globalization ${ }^{23}$ " which is linked to the "nature globalization ${ }^{24 "}$. With this virus of a complex nature, only the end of the interdependence, mobility and inclusion of societies, states, people, capital and goods could not in reality put an end to globalization. The mobility of this virus to reach the different corners of

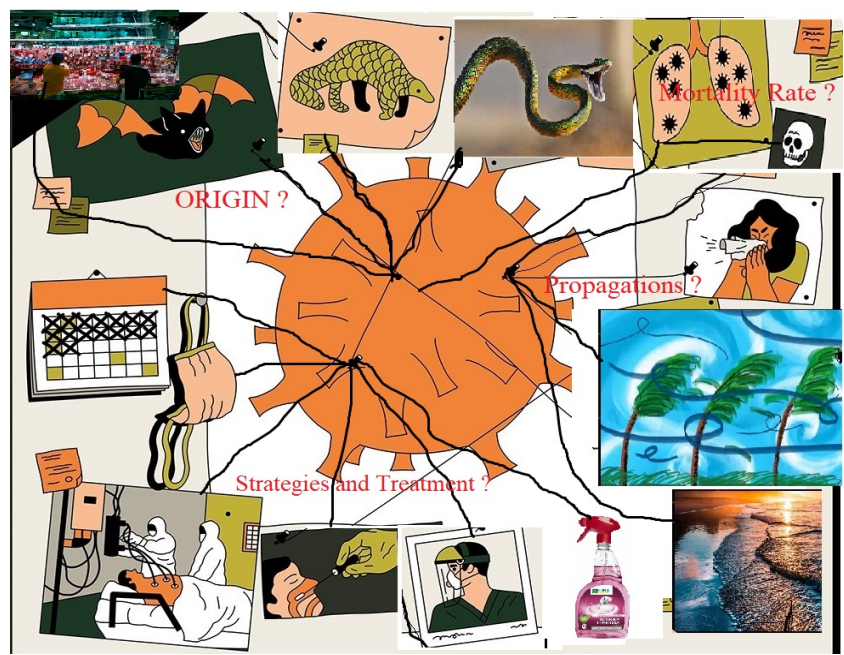

Source: The image modified by myself on the basis of the image coming from https://www.nature.com/articles/d41586-020-01315-7, accessed the $29^{\text {th }}$ November 2020.

Figure 2. COVID-19's complex nature: origin, propagation, strategies and treatment.

\footnotetext{
${ }^{20}$ Towards the beginning of the pandemic, the Western world strongly downplayed the usefulness of wearing masks in the fight against COVID-19.

${ }^{21}$ The American President Trump during these daily press briefings on the situation of COVID-19 in the United States has repeatedly referred to hydroxy-chloroquine as a drug that can be used for the treatment of patients infected with COVID-19.

${ }^{22}$ I had an unforgettable time in Wuhan city with this COVID-19 pandemic.

${ }^{23}$ Refers to the complex mobility of the virus at the global level.

${ }^{24}$ Refers to the interconnectedness of nature at the global level.
} 
the world, through its different modes of propagation, is indeed part of globalization. If human-to-human transmission and human contact with man-made products are not the only ways to be infected by this virus, even if human and man-made products remain immobile, this virus of complex nature would still have to spread throughout the world-via the transmission of human contact with nature. Humans are almost always in contact with the latter. While this one [the nature] is almost always interconnected. If this virus also circulates in nature, it means that it can almost reach different corners of the world even without intermediaries-human and man-made products. Even if the latter think they are withdrawing from globalization, and putting an end to it, nature would not have withdrawn from the dynamics of globalization - the interconnection of nature is almost permanent. While they [human and man-made products] cannot escape their contact with nature. And if the virus circulates well in nature, they-even if they remain immobile-will always be well infected by it, although the probability and rate of contamination will be minimal. On the other hand, the complexity of the nature of this virus ostensibly calls for globalization. Due to its complexity, in order to contain it, this virus should be considered as a humanity's common enemy. Therefore, cooperation and solidarity on a global scale should not be stopped or curbed, but rather, it should be amplified. Thus, the dynamism and logic of globalization should always remain as the last bulwark of humanity in its struggle with COVID-19-in the sense of being able to contain it well and quickly emerge victorious in this struggle.

\section{Nationalism and Unilateralism as COVID-19's Counter-Antidote Strategies}

Nationalism and unilateralism have been seen by some as the two major ingredients that should be added to the COVID-19's sauce to bring an end to globalization (Mearsheimer, 2018: pp. 1-319). "Nation first" and go it alone, seemed to misrepresent themselves as humanity's best antidote strategies for dealing with COVID-19. In the rise of the movements ${ }^{25}$, I quote: Let's go home! Stay in your country! Stay home! Let's protect ours! I suspect you! I accuse you! Us first and the others after!-de-globalization or the end of globalization seemed like a panacea. Nationalism and unilateralism wanted to impose themselves-abusively of course-as the best strategic antidotes to deal with COVID-19. Unnecessary and very misplaced comparisons, coupled with the COVID-19's impacts, led each state both to withdraw into itself, and to seek to impose itself or show itself to be better than others. Cries like ${ }^{26}$, I quote: I have fewer contaminated people than you! I have fewer dead people than you! I have healed more than you! I have tested more than you! I am better equipped than you! I am very fast than you! I'm safer here than you are! Not us, it's the fault of others! I don't believe in your statistics and information! So the national interest wanted to impose itself as the

\footnotetext{
${ }^{25}$ Especially in the Western world.

${ }^{26}$ An abusive competition that the States launched during this pandemic.
} 
only master on board. The collective decision-making mechanisms seem to become less important. Joint decisions and actions seem to fall into disuse. Is this the way to the end of globalization? The rise of "ad hoc nationalism", the "word war" and "conservative-progressive competition" ${ }^{27}$ has been noted time and again (Makengo, 2020b). The World Health Organization (WHO) is being singled out-especially by the Trump Administration. It is judged by the latter to be practically "useless", "non-transparent" and "China-centric" (Makengo, 2020c). The division and each for himself and God for all, wanted to impose themselves abusively as the best antidote strategies for humanity in its fight against COVID-19-just as trying to demonstrate the Figure 3 below.

This [as illustrated in the figure above] should only make the situation worse. COVID-19, by its complex nature, in order to defeat or contain it, humanity should indeed consider it as its common enemy. With nationalism and unilateralism, humanity might win the fight, but it would have to pay a very high price-the disastrous situation of COVID-19 might well continue for a very long time. Because humanity's disparate capacities to deal with COVID-19 differ greatly from nation to nation ${ }^{28}$. And also, because of its complex nature-especially its modes of propagation, which still hide many of the mysteries-humanity should only begin to turn in circles. Nations with stronger capabilities than others may well succeed in containing the virus within their own borders. But as long as the virus continues to circulate in the territories of low-capacity nations, due to its complex nature, the risk of its reappearance in the territories of high-capacity nations will always be there. Thus, strategically speaking, nationalism and unilateralism present themselves well as counter-antidote strategies to COVID-19. In

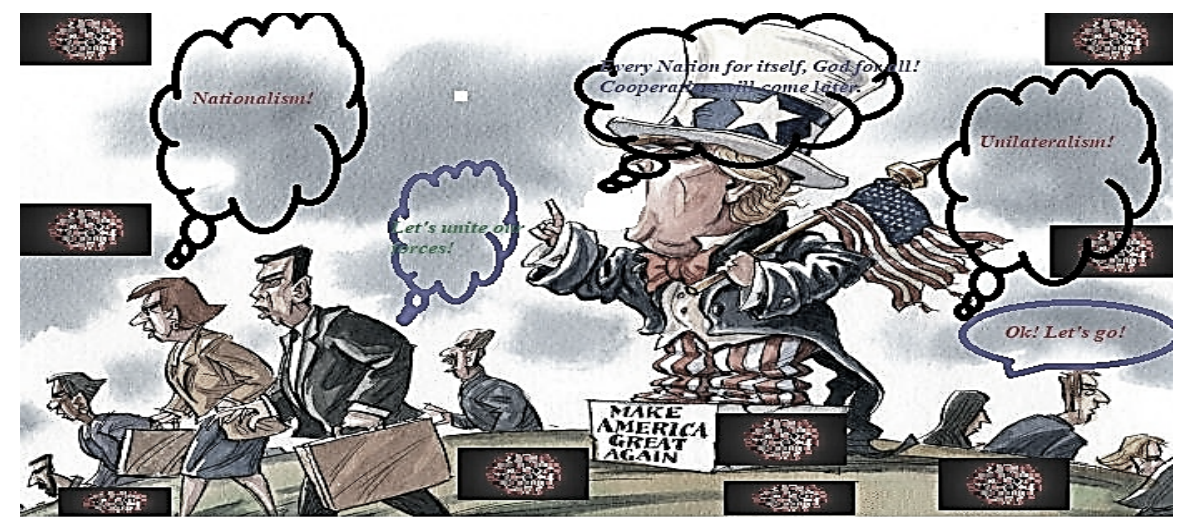

Source: The image modified by myself on the basis of the image coming from https://www.ft.com/content/7b9da60a-70b7-11e9-bf5c-6eeb837566c5, accessed the $29^{\text {th }}$ November 2020.

Figure 3. How nationalism and unilateralism wanted to be abusively imposed as humanity's best antidote strategies to deal with COVID-19?

\footnotetext{
${ }^{27}$ Competition of those who seek to maintain their dominance and power throughout the worldthe conservatives-and those who push for change in the current international structure considered unfair by them-the progressives. A competition that is dominated between United States and China.

${ }^{28}$ For example, the majority of African countries seem to be less equipped than the majority of European countries to deal with COVID-19.
} 
order to deal with COVID-19, humanity should seek to eclipse nationalism and unilateralism to some extent, and to make way for globalism and multilateralism. Rationally speaking, the latter presents itself well as the antidote strategies to better defeat and contain COVID-19 in different corners of the world. Humanity should just try to speak a single language in the face of COVID-19-it should be seen as its common enemy. The collective decision-making mechanisms should be well ahead for joint actions against COVID-19. And in this way, instead of its end, globalization should rather be pronounced in a broader way-with more global cooperation and solidarity. It is indeed a great illusion to think or believe to the end of globalization with this COVID-19 pandemic. Because the major ingredients to put an end to it [globalization]-nationalism and unilateralism - which seemed to predominate during this era of COVID-19, should also be put on the back burner-and give way to globalism and multilateralism-in order to contain and defeat the famous virus causing this pandemic.

\section{COVID-19's Impacts Nature on Social-Economic Activities}

COVID-19 has strongly moved humanity through its multiple impacts. Of course, not all of them are bad, some are just as good for humanity-to mention here only the reduction of the global temperature and the pollution levels in different world's corners ${ }^{29}$ (Makengo, 2020a: p. 52) —via the reduction of mobility and productive activities (see Figure 4). But at the level of socio-economic activities, the COVID-19's impacts are also seen in terms of crises. Apart from the loss of human lives, coupled with anxiety, it is the recessions and the consequent loss of jobs, income, supply and demand that dominate its impacts on the socio-economic activities of various global actors (Makengo, 2020b). COVID-19 has ostensibly surprised mankind. Having no other choice, humanity is forced to enter into "mask mode". No more mobility as before! The cries have gone up; I quote: let's go back home! Stay in your country! Stay home! The ground is quickly gained by COVID-19. It is the ostensible slowdown of socio-economic activities. Thus, the various indicators, both macro-economic and micro-economic, should only appear in red (Makengo, 2020b). The asphyxiation of tourism, small and medium enterprises in the slump, large enterprises, especially in the transport sector, in recession, is the fall in the growth of gross domestic product (GDP) of the world's major economies (Makengo, 2020b: pp. 123-124). The world's factory-China is hit first and the West second, but rather more severely than China. The first quarter of this year 2020 has been catastrophic for China, but rather it is worse in the second half of the year for the Western world. It is embarrassment, uncertainty, panic and the collapse of socio-economic activities. As just shown first in Figure 4 below, the COVID-19's impacts in socio-economic activities and their repercussions on different social life areas,

${ }^{29}$ COVID-19 has succeeded in virtually paralyzing a good number of productive activities, including in particular those that consume more fossil fuels, through the lockdown strategy adopted by almost all the countries ostensibly affected by this virus. Thus, satellite images in China, France, Italy... have shown considerable improvements in climate-and degree of pollution (see Figure 4). 


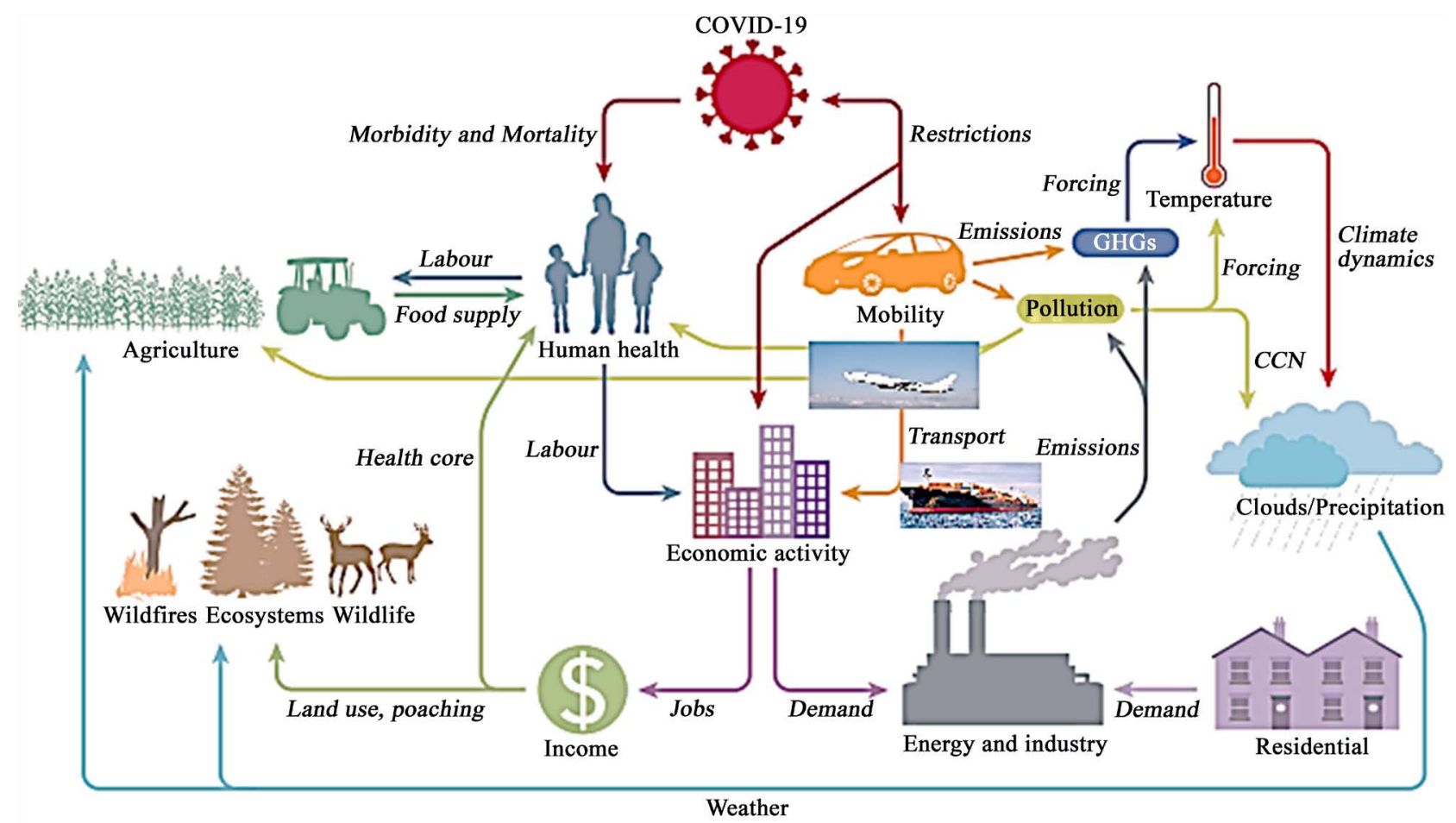

Source: The image modified by myself on the basis of the image coming from https://www.ft.com/content/7b9da60a-70b7-11e9-bf5c-6eeb837566c5, accessed the $29^{\text {th }}$ November 2020.

Figure 4. How has COVID-19 impacted the socio-economic activities of different global actors?

including environmental and demographic areas. On the one hand, no more mobility as before, and a chain of impacts ensues-through negative impacts in the transport, industrial, energy, and real estate sectors that negatively affect various macroeconomic indicators, including GDP, employment, currency, revenues, etc., but rather positively affect the ecosystem, including reductions in pollution levels and temperature. On the other hand, it is the human health both mental and physical-infection, fear, stress and death-that is negatively impacted-reduction of the labor force-with the repercussions on economic activities in different societal areas, including agriculture, affecting food security. And then, as also shown in Figure 5 below, the various negative impacts of the GDPs of the world's major economies.

And these impacts noted above, should not make us think or believe to the end of globalization. Thinking in this way with these types of impacts is a great illusion or delusion of the behavior of the various global actors affected by these impacts due to COVID-19. Because it is quite clear that once this famous virus causing COVID-19 has been contained, the era will be marked by a pronounced revival of the socio-economic activities impacted by this pandemic. These revivals should well be realized only in accordance with the dynamics of globalization. Not pronounced revivals without globalization! As just at the end of any global crisis, the ardent desires of all global actors always turn to the revival of activities shaken by the crisis. After the implementation of internal policies, it is trade, commerce and interdependencies that follow. I am thinking here of the 


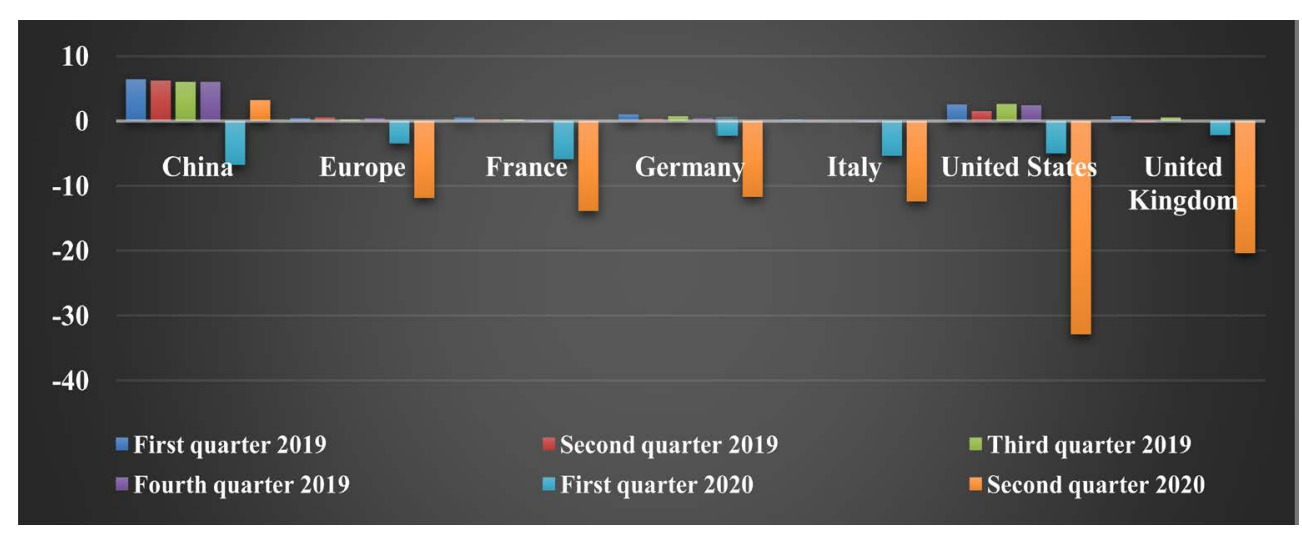

Source: Graphics designed by us based on our research data coming from Statista and Trading Economics.

Figure 5. China and the Western World: GDP Growth under the COVID-19's Crisis (2019-2020).

revival of socio-economic activities after the First and Second World Wars' crises (Berstein and Milza, Tome 1, 1996a: pp. 1-501; Berstein and Milza, Tome 2, 1996a: pp. 1-497), and those after the subprime crisis (Shiller, 2008: pp. 1-136). Rationally speaking, all the actors shaken by these impacts due to COVID-19 should also opt for the dynamics of globalization in view of the comfortable revival of their impacted activities. Moreover, following the configuration of the pre-COVID-19 world—a highly interconnected world (Steger, 2003: pp. 1-147)— globalization should always impose itself as the last bulwark of the various global actors for a pronounced revival of their socio-economic activities in the postCOVID-19 era. Strategically speaking, the costs of the end of globalization are likely to be very enormous for the various global actors. It is the path of great uncertainty, black hole and incalculable losses. Thus, with the COVID-19's impacts, particularly on socio-economic activities, it is practically absurd to shout, believe or think to the end of globalization.

\section{Global Complex Interdependence}

Robert Keohane and Joseph Nye, in their book, I quote: power and interdependence, developed the theory of complex interdependence. The latter, I quote: "stresses the complex ways in which as a result of growing ties, the transnational actors become mutually dependent, vulnerable to each other's actions and sensitive to each other's needs' (Rana, 2015: pp. 290-297; Keohane and Nye, 1977: pp. 1-330). Here I am seeing this complex interdependence at the global level-not only to talk about the complex mobility of societies, states, nations, individuals, capital, goods, information and knowledge, but also their complex inclusion in the global level. COVID-19 has come to find humanity in a situation of complex interdependence. This is indeed the expression of globalization, which has become increasingly pronounced and complex since the end of the Second World War. In order to understand it, it is best to take a step backwards a little, just a little bit, with a reading and rereading of the history of international relations in the post-World War II period. In particular, it is almost the history of the rise 
and fall of "American globalization" or American exports around the world after World War II, and the rise of other states in the international arena (Kennedy, 1988: pp. 1-677). The story that I would not have declined everything here in detail. It covers several aspects at the same time: economic-financial, geopolitical, institutional, relational, military, social, cultural, technological...

Just synthetically, at the end of World War II and the beginning of the Cold War between United States and Soviet Union (USSR), the European powers and Japan were ostensibly negatively impacted by the war (Berstein and Milza, Tome 2, 1996b). Decolonization movements were launched in different corners of the world-ostensibly supported by US and USSR (Newsom, 2001: pp. 1-241). United States-less impacted by the war-alone, emerges stronger than other industrial powers in the post-World War II period (Berstein and Milza, Tome 2, 1996b). Thus, the consequence seems to be simple here, others hardly produce at all-their industries are all but sabotaged by the war. It is United States that should remain almost the sole producer of goods throughout the world-also mainly because of the industrial weaknesses of its direct competitor, the USSRobviously undermined by the war (Berstein and Milza, Tome 2, 1996b). United States is indeed becoming not only the main provider of global public goods (Kaul, Conceicao et al., 2003: pp. 1-635), both as a body and a mechanism-the international institutions, multilateral platforms-United Nations and its corollaries (Berstein and Milza, Tome 2, 1996b). But also, they are becoming the world's main supplier of both material and consumer goods (Gelb, 2010). It is the American economic boom after World War II. Therefore, the issues of raw material supply and market should only rise to be at the heart of its stability and economic boom. Thus, the Marshall Plan should only come to support the demand for its productions-it's just a question of the law of supply and demand for the United States (Gimbel, 1976: pp. 1-344). Europe and Japan are well financed by the latter. Communities have begun to form in Europe, but also in other continents ${ }^{30}$. Also, the so-called Third World and developing countries began to rise up for their organization ${ }^{31}$. In spite of its ideological, geopolitical and military competitions that were constantly rising with USSR-bay of pigs, Berlin wall, Cuban missile crisis (Berstein and Milza, Tome 2, 1996b). The ground was almost empty for the expansion of American investments throughout the world and for its quasi-monopoly in world exports.

Very soon, around 1970s and 1980s, the old industrial countries-asleep because of the negative impacts of the war on their economic structures-began to wake up-especially West Germany and Japan. The Marshall Plan and other aids worked well for Europe and Japan. Just at the beginning, it seemed to work well for United States as well. But just afterwards, it was going badly against them [United States]. It was the beginning of the decline of the American qua-

\footnotetext{
${ }^{30}$ Especially with the European Coal and Steel Community-the current European Union, the Union of African Organizations-currently the African Union, the Association of Southeast Asian Nations (ASEAN)...

${ }^{31}$ The Bandung conference in 1955, Group of 77 (G77) in 1964...
} 
si-monopoly in world exports, the beginning of the decline of "American globalization," and the rise of the old European industrial powers and Japan (Otsubo, 2007: pp. 1-73.). It is the rise of global production and global demand for raw materials, and thus the rise of global interdependence, mobility and inclusion. Global trade competition increasingly began to shake up "American globalization"-especially with the first oil shock of 1973. At the same time, United States-already hit by the effects of the Vietnam War-is gradually managing to improve its relations with $\mathrm{USSR}^{32}$. And also, they [United States] manage to improve its relations with $\mathrm{China}^{33}$ (Ali, 2005: pp. 1-276) -and as a result to its reform end opening up policy (Yu et al., 2017: pp.1-44). Unfortunately, very quickly again, it is the return of the great hostilities and competitions between United States and USSR - the Ronald Reagan's doctrine (McMahon, 2003: pp. 143-168). Military spending, which had already been increasing since the beginning of the Cold War, now took the direction of an exponential rise (Coker, 1983: pp. 1-163) -also for the raw materials' demand-particularly for oil ${ }^{34}$ and those used in high-tech industries. The level of global interdependence is thus expected to increase further. Eyes have ostensibly turned to the Middle East and Africa $^{35}$ (McMahon, 2003). And a few looks in Latin America and the Caribbean ${ }^{36} \ldots$ It is the crisis that is looming in American society, the American economy no longer seems to be performing well in the $1980 \mathrm{~s}^{37}$ (Katz, 2010: pp. 1-13). The big American firms, breathless by the commercial competition that was constantly turning against them, quickly revived the ideas of free trade (Gelb, 2010; Goldstein, 2007: pp. 1-406). It is the fiscal barriers that should ostensibly disappear in the relations and exchanges between States at the global level. The institutions, both mechanisms and bodies, were put in place until the 1990s with the creation of NAFTA - now United States-Mexico-Canada Agreement (USMCA) - and the rise of WTO, the heir to GATT. Once again, it is the increase in the level of trade around the world in raw materials, finished products and goods of all kinds-and thus again, it is the increase in the level of global interdependence, mobility and inclusion.

And the new information and communication technologies began to rise more and more around the same 1970s-to reach their current state of sophistication in the era of the fifth generation of standards for cell phones (G5) (Graaf and Washida, 2006: pp. 1-316; Nye, 2004: pp. 1-231). But also, it is the great beginning of the push to the pronounced offshoring of large companies, especially of American companies-in search of the cheapest labor, in order to be able to maximize their profit-because of the high cost of American labor, compared to

\footnotetext{
${ }^{32}$ The détente moment-the Moscow summit, Strategic Arms Limitation Talks (SALT)...

${ }^{33}$ Its relations are no longer good with Khrushchev's USSR.

${ }^{34}$ Especially with the second oil shock of 1979

${ }^{35}$ The invasion of Afghanistan, intervention in Lebanon, the wars in Angola and the Democratic Republic of Congo...

${ }^{36}$ With the 1973 coup d'état in Chile and the intervention of Grenada...

${ }^{37}$ Especially with the rising unemployment rate at $10.8 \%$ - hence Reagan's economic stimulus policies. Some people stopped talking about its overtaking by Japan as early as the 1970s.
} 
other states (Gelb, 2010). This has led not only to a decline in US exports around the world, but also, once again, to an increase in the level of global interdependence, mobility, and inclusion. At the same time, USSR was also constantly torpedoing itself economically-with its late reforms: glasnost and perestroika (McMahon, 2003). It is the end of the Cold War, the fall of the Berlin Wall in 1989 and the break-up of the USSR to 15 states in 1991 (Lightbody, 1999: pp. 1-141). The end of history is signed (Fukuyama, 1989), victory of the market economy, an empty field for the projection of American liberal hegemony globalization (Mearsheimer, 2018) - it is the wind of democratization throughout the world (Blum, 2013: pp. 1-355). But very quickly, history reappeared, with the clash of civilizations (Huntington, 1993) — the Gulf War, the Somali War, the Rwandan Genocide, the attacks of September 11, 2001, the war in Afghanistan, the war in Iraq... A pathetic entry into the twenty-first century! And on the one hand, the European Union continues its journey of enlargement, integration and progress (Beringer, Maier and Thiel, 2019: pp. 1-207). Russia, which has replaced the USSR, is trying to rise gradually, especially with the arrival of Vladimir Putin at the beginning of this twenty-first century (Stuermer, 2008: pp. 1-296). On the other hand, with the United States' support, China joined the World Trade Organization in 2001 (Levy, 2018). The investment boom on the Chinese territory-its mainland market of more than a billion consumers, the abundance and cheaper cost of its labor, its flexible governance... have strongly attracted large companies (PWC and CDRF, 2013: pp. 1-31). The offshoring of the twenty-first century has begun, and it is the further rise of the level of global interdependence, mobility and inclusion. And the subprime crisis has once again led to a decline in US exports around the world (Mohan, 2009: pp. 1-38). Rather, it is the rise of China to become virtually the " world's factory "—with its "mega project" of the Belt and Road Initiative (Zhang, Alon and Lattemann, 2018: pp. 1-358), the creation of the Asian Infrastructure Investment Bank (Danner, 2018: pp. 1-207) and the New Development Bank with the BRICS (Stuenkel, 2015: pp. 1-211). As a result, trade is further intensified at the global level, new markets and multilateral platforms are created from all over the world, a strong increase in global production, demand for raw materials, global exports and the high-tech boom. It is once again the rising level of global interdependence, mobility and inclusion. As just shown in the Figure 6 below.

This global interdependence, which has become increasingly complex since the end of the Second World War, could not be extinguished overnight-especially not with COVID-19. The latter, with its various impacts on it [global complex interdependence], I quote: go back home, stay in your country, stay home, I suspect you, I accuse you, and the rise of "ad hoc nationalism", has not managed to annihilate this complex global interdependence-for arriving to put an end to globalization. There has just been a reduction in the level of this complex interdependence-through the "quasi-apocalyptic immobility" that humanity has experienced. But of course, this observed immobility does not affect all areas of 

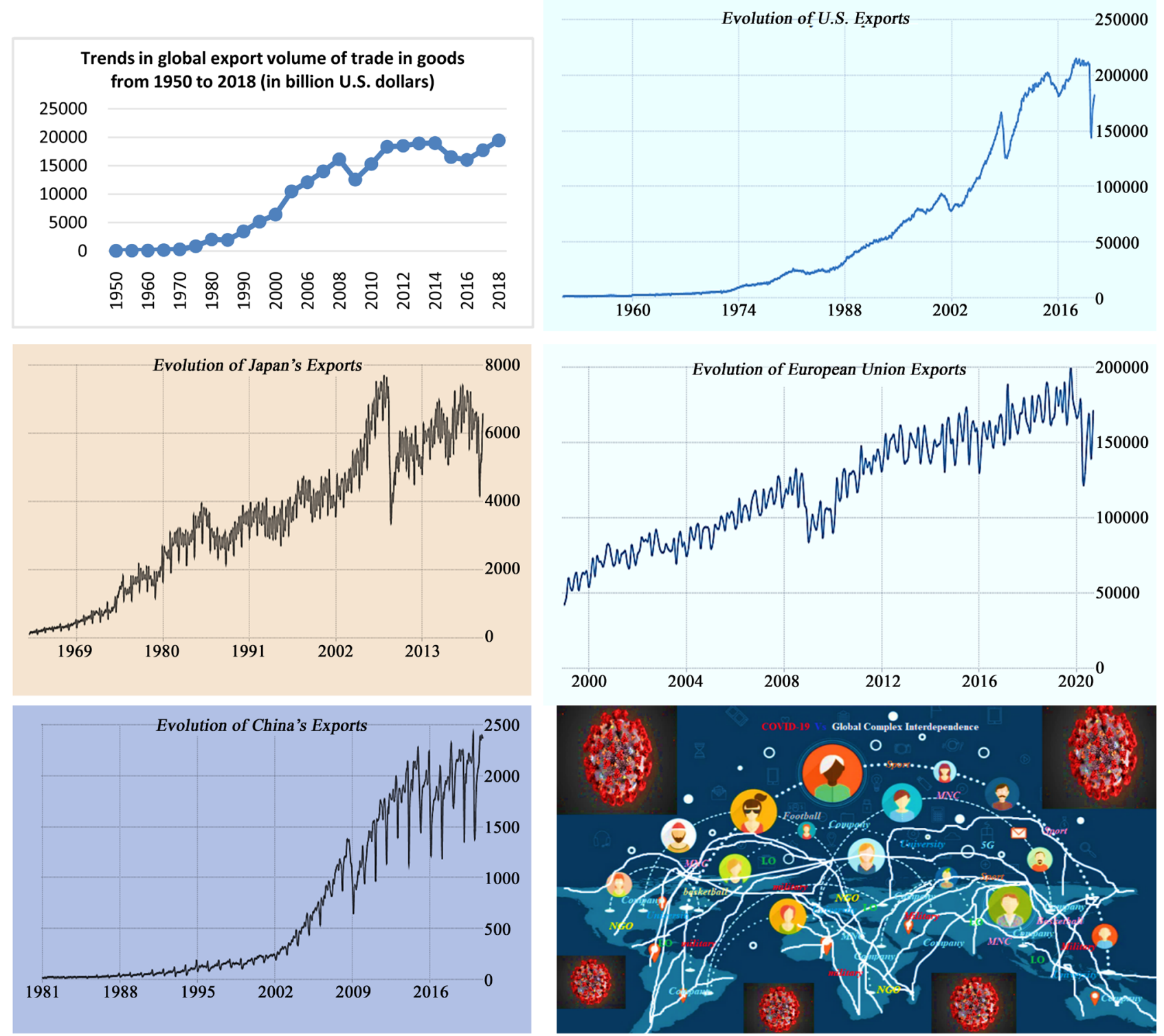

Sources: figures designed and modified by myself on the basis of data coming from www.statista.com, tradingeconomics.com and iicshumanities1.weebly.com, accessed the $29^{\text {th }}$ November 2020.

Figure 6. Evolutionary history of global, US, Japan, European union and China exports + COVID-19 vs global complex interdependence.

society, and has moreover manifested itself in the physical dimension, in opposition to the digital one. Because if the people's mobility and the exchange of certain goods have ostensibly been reduced, those affecting the medical field have intensified. And also, if this interdependence, mobility and inclusion have ostensibly been reduced in a physical way, with the new information and communication technologies, they have rather intensified in a digital way. Thus, it is not the COVID-19's impacts that could put an end to globalization. The complex global interdependence that serves the globalization's survival shield, COVID19 , has not been able to destroy it, and would not have been able to do so-just depending on the nature of its impacts on humanity. 


\section{Conclusion}

Why couldn't the COVID-19's impacts to humanity bring an end to globalization? This was the central question that ostensibly filled the debate and discussion of this paper. The objective of the latter was not only to make a contribution to the existing literature on the theme of globalization in the wake of COVID-19. But also to manage to sweep away, following the strategic analysis approach, tinged with globalism, all the ideas abusively thinking to the end of globalization with the COVID-19 pandemic, and to implicitly show humanity the rational path it should follow in its fight against COVID-19.

COVID-19 came ostensibly to shake up and shake humanity. Caution! Help! Let's go back home! Stay in your country! Stay home! I suspect you! I accuse you! Let's collaborate! Solidarity! Myself first, others after! Let's protect and bring our companies and investments back home! Such are the cries of humanity-which came from everywhere-that have been rising during this COVID-19 period. These cries are just an expression of the COVID-19's impacts to humanity. The "quasi-apocalyptic silence" quickly spread to popular and crowded places-bus stops, train stations, airports and ports... The level of global interdependence, mobility and inclusion — in its physical dimension, as opposed to digitalis conspicuously reduced. The socioeconomic and financial crises have rapidly escalated. The word war quickly began. The conservative-progressive competition rose sharply. "Ad hoc nationalisms" and unilateralism soon appeared-to misrepresent themselves as a panacea. Thus, some believed, shouted, thought [and others still continue to think] abusively to the end of globalization with these COVID-19's impacts to humanity-the end of interdependence, mobility and inclusion at the global level.

And through this paper, my point is very simple and clear. I argue that globalization could not end with the COVID-19's impacts. On the contrary, it should instead be amplified. And I have supported my point with five (5) core arguments, which are:

1) COVID-19 As A pro-globalization messenger: "You are living in a global village" - as a pro-globalization messenger, it could not stop globalization. It has just come to reveal and challenge humanity with its message, which clearly shows that we are living in a global village.

2) Virus Complex nature-the complexity of the nature of the virus causing COVID-19, well compels humanity to stay in the dynamics of globalization for its rational victory against this virus. Thus, instead of its end, globalization should rather well impose itself as the last bulwark of different global actors in the sense of better containing COVID-19.

3) Nationalism and Unilateralism as COVID-19's counter-antidote strategiesnationalism and unilateralism are indeed the two major ingredients that should be added to COVID-19's sauce to end globalization. While strategically speaking, they appear to be the humanity's counter-antidote strategies in the sense of winning its fight with COVID-19 at a lower cost. Thus, both should well come 
out of the game, to make way for globalism and multilateralism.

4) COVID-19's Impacts Nature on Social-economic activities-after COVID-19, it is the time for the revival of socio-economic activities negatively affected by it. And depending on the configuration of the world before COVID-19-a highly interconnected world - this revival of activities could take place in a pronounced way only in the logic of the dynamics of globalization.

5) Global Complex Interdependence-The world, which has become increasingly complex since the end of the Second World War with the push of "American globalization", through the rise of old industrial powers, until the beginning of the twenty-first century with the rise of China, but also the rise of new information and communication technologies, cannot be undone or faded overnight. And the COVID's impacts-as pinned here in this paper-could not succeed in destroying this Global Complex Interdependence.

Taken together, all these five arguments better explain why globalization could not end with the COVID-19's impacts. It is up to humanity to understand and internalize this reality, and to assimilate and learn the different lessons that COVID-19 has come to give it. Instead of crying out to the end of globalization, it is time for humanity to organize and act together in a coordinated way to better contain COVID-19, and to start already preventing the next pandemic. Would there still be any? When would it be for when? Who knows? How would it still impact humanity? Imagine that it would start hitting less equipped countries first? The future is still very uncertain. Thus, with this COVID-19 pandemic, it is time for humanity to become active, reactive and proactive. Otherwise, it is another disaster it is still preparing for. Let's avoid the worst in the days ahead! But the question remains here, what if globalization came to an end? What next? Ultra-nationalism? Internationalism? Regionalism? Inter-regionalism? Or just, what then?

\section{Acknowledgements}

I thank here my models, elders and masters, for their various trainings, to name just a few: Professor Zhao Huaipu, China Foreign Affairs University (CFAU); Professor Su Hao (CFAU); Professor Zhu Dandan (CFAU); Professor Hu Zongshan, Central China Normal University (CCNU); Professor Zhao Changfeng (CCNU); Professor Zhang Xian (CCNU); Professor Liu Mingzhou (CCNU); Professor Wang Yonghui (CCNU); Professor Théo-Macaire Kaminar Nsiy, University of Kinshasa (UNIKIN); Professor Célestin Musao Kalombo (UNIKIN); Professor Nnkere Ntanda Nkingi (UNIKIN); Professor Kazumba K. Tshiteya (UNIKIN); Professor Jean-Pierre LotoyIlango-Banga (UNIKIN); Professor Jean Abemba Bulaimu (UNIKIN); Professor Émile Bongeli Yeikeo Ya Ato (UNIKIN); Professor Anicet Hénoc Nkwimi Akol (UNIKIN); Professor Jean-Gérard Baende Ekungola (UNIKIN); Professor Héritier Mambi Tunga-Bau (UNIKIN); Professor Jacques Tshibwabwa-Kuditshini (UNIKIN); Professor Arsène Bwenge Mwaka (UNIKIN); Professor Guy Aundu Matsanza (UNIKIN); Professor Jean Liyongo Empengele (UNIKIN); Professor Godé Atshwel-Okel (UNIKIN); Professor Tho- 
mas Mawanzi Manzenza (UNIKIN); Professor Apollinaire Ipaya Ikoko (UNIKIN); Professor Anselme Meya Ngemba (UNIKIN); Professor Patience Kamanda; Professor Eric Kazekele Mbele (UNIKIN); Professor Germain Kuna Maba Mambuku (UNIKIN); Professor Patrice Bénis Mukulu Nduku (UNIKIN); Professor Richard Kakesa Malundangu (UNIKIN); Professor Michel Bisa Kibul (UNIKIN); Chief of Works Willy Kalala (UNIKIN); Professor Thomas E. Patterson, Harvard University; Dr. Benjamin S. Carson, University of Michigan...

And finally, I sincerely thank here my friends, who never cease to support me in my writings, to mention only: Klaudia Misztal; Murielle Mwambay Musao; Vinny Lofoma Kombambe; Richard Motobebo Tewunipe...

\section{Conflicts of Interest}

The author declares no conflicts of interest regarding the publication of this paper.

\section{References}

Ali, M. (2005). US-China Cold War Collaboration: 1971-1989. London: Routledge.

Beringer, S. L., Maier, S., \& Thiel, M. (2019). EU Development Policies: Between Norms and Geopolitics. Berlin: Springer International Publishing, Palgrave Macmillan. https://doi.org/10.1007/978-3-030-01307-3

Berstein, S., \& Milza, P. (1996a). Histoire du XXe siècle. Tome 1: 1900-1945: La Fin du monde européen. Paris: Hatier.

Berstein, S., \& Milza, P. (1996b). Histoire du XXe siècle. Tome 2: 1945-1973: Le Monde entre guerre et paix. Paris: Hatier.

Blum, W. (2013). America's Deadliest Export: Democracy-The Truth About US Foreign Policy and Everything Else. London: Zed Books.

Buckman, G. (2004). Globalization: Tame It or Scrap It? Mapping the Alternatives of the Anti-Globalization Movement. London: Zed Books.

Coker, C. (1983). US Military Power in the 1980s. London: Palgrave Macmillan.

Crozier, M., \& Friedberg, E. (1977). L'Acteur et le Système. Paris: Éditions du Seuil.

Danner, L. K. (2018). China's Grand Strategy: Contradictory Foreign Policy? London: Palgrave Macmillan.

Fukuyama, F. (1989). The End of History? The National Interest.

Gelb, L. H. (2010). GDP Now Matters More than Force: A U.S. Foreign Policy for the Age of Economic Power. Foreign Affairs, November/December Issue.

Gimbel, J. (1976). The Origins of the Marshall Plan. Redwood City, CA: Stanford University Press.

Goldstein, N. (2007). Globalization and Free Trade. New York: Infobase Publishing.

Huntington, S. (1993). The Clash of Civilizations? Foreign Affairs. https://doi.org/10.2307/20045621

Jamil, J. (2011). Globalism and Comparative Public Administration. Boca Raton, FL: CRC Press. https://doi.org/10.1201/b11088

Katz, L. F. (2010). Long-Term Unemployment in the Great Recession. Testimony for the Joint Economic Committee U.S. Congress, Hearing on "Long-Term Unemployment Causes, Consequences and Solutions" Cannon House Office Building, Room 210, April 
29.

Kaul, I., Conceicao, P. et al. (2003). Providing Global Public Goods: Managing Globalization. Oxford: Oxford University Press. https://doi.org/10.1093/0195157400.001.0001

Kennedy, P. (1988). The Rise and Fall of the Great Powers: Economic Change and Military Conflict from 1500 to 2000. London: Unwin Hyman.

Keohane, R. O., \& Nye, J. S. (1977). Power and Interdependence: World Politics in Transition. Boston, MA: Little, Brown \& Co.

Levy, P. (2018). Was Letting China into the WTO a Mistake? Why There Were No Better Alternatives? Foreign Affairs, April 2.

Lightbody, B. (1999). The Cold War. London: Routledge.

Makengo, B. M. (2020a). Competitive Globalization and Quest for Strategic Minerals: DRC's Cobalt at the Heart of New Global Stakes, towards the Resource's Trap? International Journal of Management Sciences and Business Research, 9, 51-75.

Makengo, B. M. (2020b). COVID-19 and Power Games in Africa: Can Sino-African Relations Withstand? International Journal of Management Sciences and Business Research, 9, 113-129.

Makengo, B. M. (2020c). COVID-19 and US-China Word War: What Should Africa Do? International Journal of Innovation and Scientific Research, 48, 188-203.

Makengo, B. M. (2020d). Globalization and Power Strategies: A Look at the US-China Trade War. International Journal of Management Sciences and Business Research, 9, 117-143.

McMahon, R. J. (2003). Cold War. A Very Short Introduction. Oxford: Oxford University Press. https://doi.org/10.1093/actrade/9780192801784.001.0001

Mearsheimer, J. J. (2018). The Great Delusion: Liberal Dreams and International Realities. London: Yale University Press. https://doi.org/10.2307/j.ctv5cgb1w

Mohan, R. (2009). Global Financial Crisis: Causes, Impact, Policy Responses and Lessons. Working Paper No. 407, Stanford, CA: Center for International Development, Stanford University.

Newsom, D. D. (2001). The Imperial Mantle: The United States, Decolonization, and the Third. Bloomington, IN: Indiana University Press.

Nye Jr., J. S. (2004). Power in the Global Information Age: From Realism to Globalization. London: Routledge. https://doi.org/10.4324/9780203507292

Otsubo, S. T. (2007). Post-War Development of War Development of the Japanese Economy the Japanese Economy. Course for EDP\&M Program, GSID, Nagoya University.

PWC and CDRF (2013). Choosing China: Insights from Multinationals on the Investment Environment. China Development Forum, Survey Report.

Rana, W. (2015). Theory of Complex Interdependence: A Comparative Analysis of Realist and Neoliberal Thoughts. International Journal of Business and Social Science, 6, 290.

Rodrik, D. (2011). The Globalization Paradox: Democracy and the Future of the World Economy. New York: W. W. Norton \& Company. https://doi.org/10.1355/ae28-3k

Shannon, A. (2002). Sustainability: Think Globally, Act Locally. Metroscape, Summer 2002, 26-29.

Shiller, R. J. (2008). The Subprime Solution: How Today's Global Financial Crisis Happened, and What to Do about It. Princeton, NJ: Princeton University Press.

Steger, M. B. (2003). Globalization: A Very Short Introduction. Oxford: Oxford University Press.

Stuenkel, O. (2015). The BRICS and the Future of Global Order. Lanham, MD: Lexington 
Books.

Stuermer, M. (2008). Putin and the Rise of Russia: The Country That Came in from the Cold. London: Weidenfeld \& Nicolson.

Van Der Graaf, S., \& Washida, Y. (2006). Information Communication Technologies and Emerging Business Strategies. Hershey, PA: IGI Global. https://doi.org/10.4018/978-1-59904-234-3

Xi, J. P. (2014). The Governance of China. Beijing: Foreign Languages Press.

Xi, J. P. (2017). The Governance of China II. Beijing: Foreign Languages Press.

Yu, J. et al. (2017). From Deng to Xi: Economic Reform, the New Silk Road, and the Return of the Middle Kingdom. Lse Ideas Special Report.

Zhang, W. X., Alon, I., \& Lattemann, C. (2018). China's Belt and Road Initiative: Changing the Rules of Globalization. Palgrave Studies of Internationalization in Emerging Markets. 